\title{
Adaptive Technology of Using Backhoes for Full Coal Extraction
}

\author{
Tyulenev Maxim A. ${ }^{\mathrm{a}}$, Khoreshok Alexey A. ${ }^{\mathrm{b}}$, \\ Garina Ekaterina A. ${ }^{\mathrm{c}}$, Danilov Sergey N. ${ }^{\mathrm{d}}$ \\ T. F. Gorbachev Kuzbass State Technical University \\ Kemerovo, Russian Federation \\ a tma.geolog@kuzstu.ru, b haa.omit@kuzstu.ru \\ c garina_e@mail.ru, ${ }^{\mathrm{d}}$ trudarmeiski@rambler.ru
}

\author{
Zhironkin Sergey A. \\ T. F. Gorbachev Kuzbass State Technical University \\ Kemerovo, Russian Federation \\ National Research Tomsk Polytechnical University \\ Tomsk, Russian Federation \\ zhironkin@inbox.ru
}

\begin{abstract}
Hydraulic backhoes are widely used in Kuzbass (Western Siberia, Russia) because the level of coal loss during their operation is much lower compared with traditional quarry excavators - shovels. However, one of the mining enterprises' designing problems is insufficient consideration of technological possibilities of this type of equipment, which leads to additional losses of coal and economic effect reduce. This article presents an approach to adaptation of the slope height considering the capabilities of backhoes in seam extracting which can sufficiently decrease coal losses and intensify open pit mining. This approach is based on a system of mining and geometrical calculations, allowing carrying out an accurate selection of equipment and technology to adapt the use of hydraulic backhoes to minimize coal losses.
\end{abstract}

Keywords - slope height; backhoes; coal losses; fullness of coal extracting; economic efficiency; fullness of excavation

\section{INTRODUCTION}

At present time, hydraulic backhoes are widely used on open pits of Kuzbass. First of all, this kind of excavation and loading equipment was specially designed for excavating coal seams, because the fullness of coal extracting by such excavators is significantly higher than by shovels (EKG type in Russian manufacturers' classification). But as a rule, extracting capabilities of excavators are not taken into account during drawing open pits projects and plans. To determine the height of the mining layer kinematic scheme of excavators provided by the manufacturers are often accepted. With a general correctness of these schemes the excavator work in coal-rich area could result in unplanned losses of coal, which would cause economic damage to the open pit.

We considered open pit mining of flat seams, widely spread in Kuzbass. We used the open pit "Raspadsky" as an example. JSC "Open pit Raspadsky" is a coal producing company in the Kemerovo region [1]. The company is a part of the Russian holding "Raspadskaya Coal Company". The open pit started mining operation in August, 2004. Since 2007, the open pit has been working licensed segment "Open pit Glukhovsky," since 2014 licensed segment "Raspadsky IX-XI» has been involved in operation; in 2017 licensed segment "Dorozhnyi" will be involved in operation. The total coal deposit volume is about 132 million tons. Economic lifetime with planned capacity of 5 million tons of coal per year is set for about 27 years. Productive deposits of open pit «Raspadsky» compose a group of seams with bedding from a gentle sloping seams to flat seams: dip angles are 15-24 degrees, sometimes up to 30 degrees.

\section{MATERIALS AND METHODS}

For open pit mining with the coal seams having an angle less than 35 degrees the excavation equipment of a hydraulic backhoe Liebherr R984 type is used. In soil of coal layers with 5 meters height the triangles of excavator shortfalls are beginning to appear. To solve this problem, it is necessary to reduce the layers' height for such kinds of seams to the value at which coal loss in the soil will be excluded or minimized. If to keep working according to the parameters specified in the project documentation, then during the process of open pit mining operations the coal losses will begin to increase and the company will start losing profits [2-4]. And now improving economic efficiency of coal open pits is the key to attracting new investment in the industry of Kuzbass and its development in general, and the outcome of mining enterprises on a new stage of modernization [5-8].

\section{RESULTS}

We considered the front of the mining slope of 250 meters. In open pit mining the seams with dip angles of 30 degrees the amount of operating losses from shortage of triangles will be $222.5 \mathrm{~m}^{3}$. But at the seams dip angles of $25 \mathrm{de}-$ grees the amount of loss increases up to approx. $750 \mathrm{~m}^{3}$ (Fig. 1, Fig. 2). 


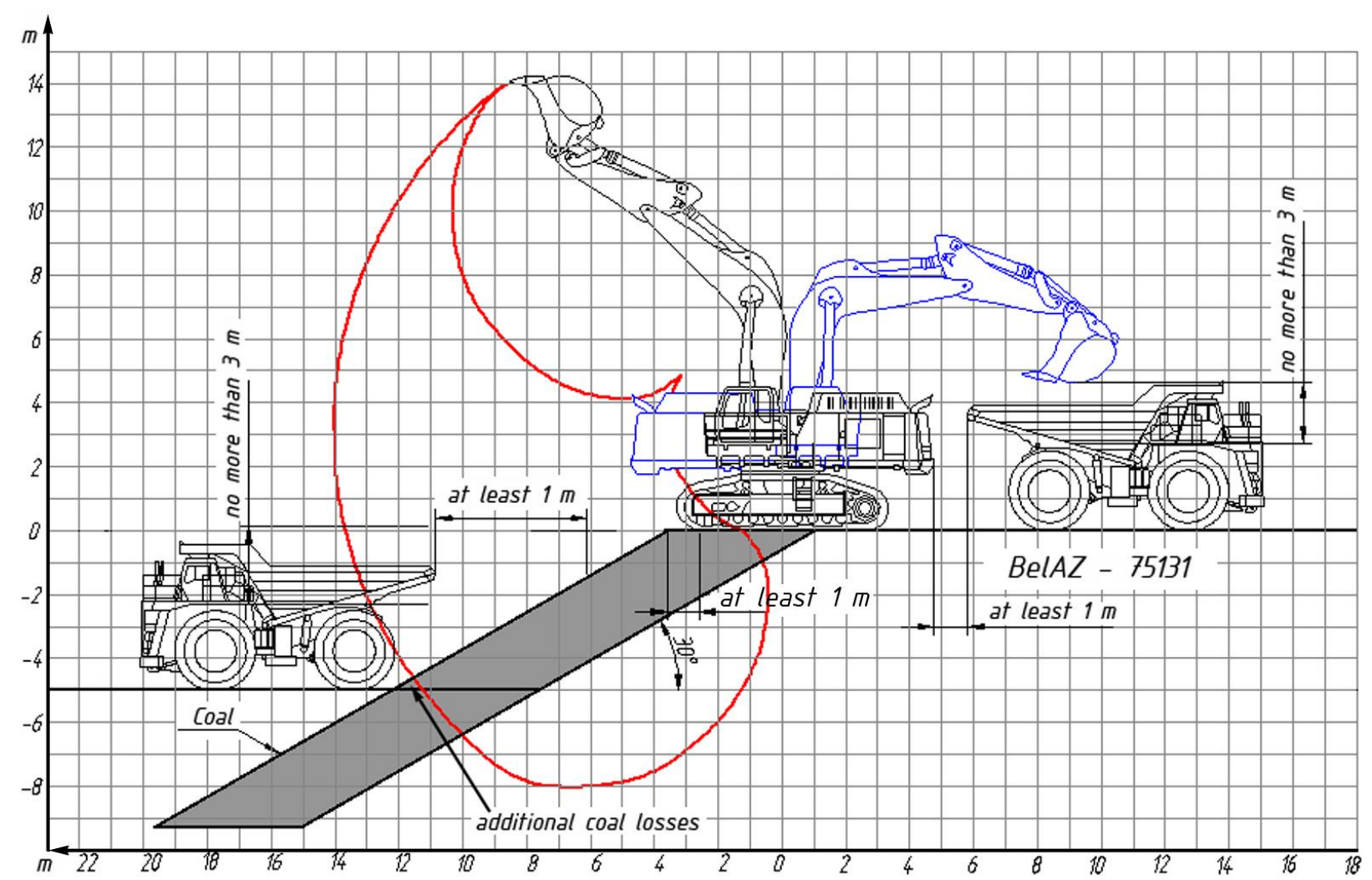

Fig. 1. The scheme of coal losses appearing during seam excavation with bid angle of 30 degrees and the layer's height of $5 \mathrm{~m}$ by shovel Liebherr R984

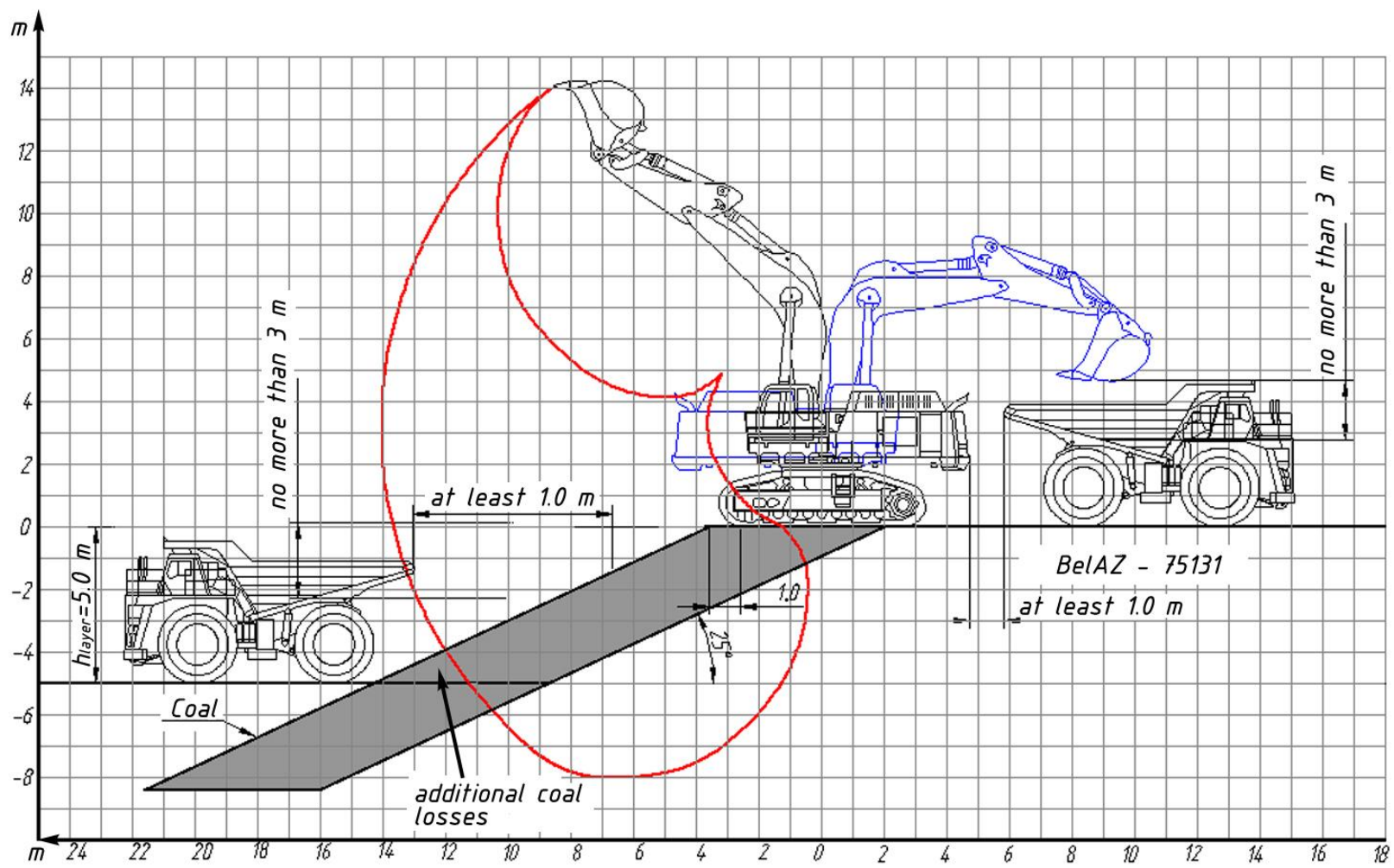

Fig. 2. The scheme of coal losses appearing during seam excavation with bid angle of 25 degrees and the layer's height of $5 \mathrm{~m}$ by shovel Liebherr R984 
Analysis of the schemes on Fig.1 and Fig.2 allowed us coming to the following conclusion. Using backhoe Liebherr R984 for excavating coal slope (the working layer) of $5 \mathrm{~m}$ height results in additional and non-planned coal losses [9] if the dip angle of processed seam is 30-32 degrees. Considering the fact that on "Open pit Raspadsky" almost all processing seams have the dip angles less than 30 degrees, it is necessary to correct the height of extracting coal layer to the reduction.

\section{DISCUSSION}

Except un-excavating problem of using shovels for extracting coal seams, there is another one, also highly important. For coal seams with height of 5 meters and bid angles of coal layers of 20-25 degrees, loading into the dump trucks can be performed only at the level of state, since at the lower loading dump truck will be located outside the kinematic capabilities of the excavator's boom movement (for Liebherr R984 - see Fig. 2).

In the analysis of the kinematic scheme of the hydraulic backhoe Volvo-460 it was found that un-excavating zone at extracting the layer to a height of 5 meters, appears at seams bid angles less than 40 degrees. Fig. 3 and 4 show formation of coal losses zone at bid angle of seam layers of 25 and 30 degrees respectively.

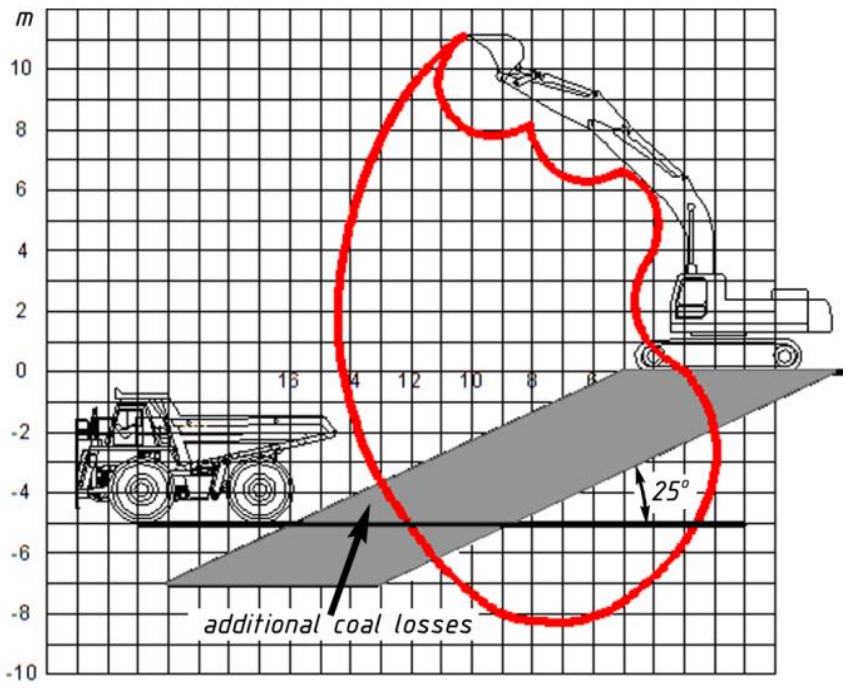

Fig. 3. The scheme for coal losses calculation during mining the seam with bid angle of 25 degrees and layers of $5 \mathrm{~m}$ by hydraulic backhoe Volvo EC460

The analysis of Fig. 3 and Fig. 4 has shown the resemblance of coal losses genesis for using hydraulic backhoes Volvo EC460 to Liebherr R984. Because working parameters (especially digging radius) of Volvo EC460 are generally less than of Liebherr R984, the additional coal losses would appear for higher dip angles - up to 40 degrees. This value was defined by us using graph-analytical method.

To increase the fullness of extracting coal it is necessary in each case to adjust the parameters of mining layers as in the absence of un-excavating zones the loss value is reduced $[10,11]$. We calculated recommended height of the excavating layer of the coal seam for different bid angles for two wide spread models of backhoes - Liebherr 984C (Germany) and Volvo EC460 (Sweden). The bucket capacity is 2.9$8.0 \mathrm{~m} 3$ (Liebherr) and 1.8-3.6 m3 (Volvo). Results of calculations are presented in Table 1.

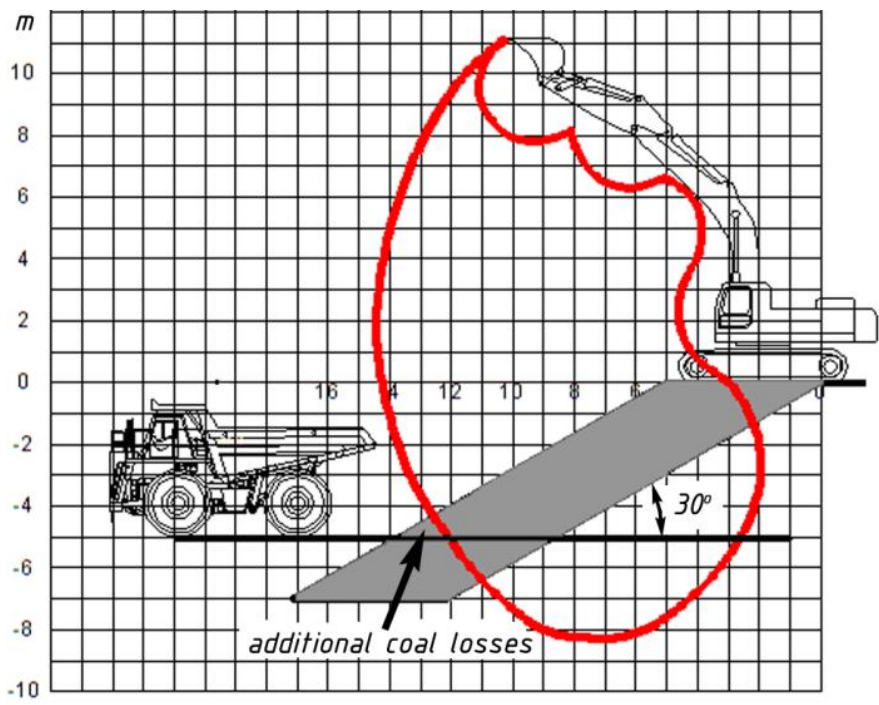

Fig. 4. The scheme for coal losses calculation during mining the seam with bid angle of 30 degrees and layers of $5 \mathrm{~m}$ by hydraulic backhoe Volvo EC460

TABLE 1. Recommended height of the excavating layer of the coal seam with different bid angle

\begin{tabular}{|c|c|c|}
\hline $\begin{array}{c}\text { Bid angle } \\
\boldsymbol{\alpha}, \text { degrees }\end{array}$ & $\begin{array}{c}\text { The layer's height } \\
\text { H, m, for backhoes } \\
\text { Liebherr 984C }\end{array}$ & $\begin{array}{c}\text { The layer's height } \\
\text { H, m, for backhoes } \\
\text { Volvo EC460 }\end{array}$ \\
\hline 15 & 2.5 & 2.0 \\
\hline 20 & 3.1 & 2.8 \\
\hline 25 & 3.8 & 3.2 \\
\hline 30 & 4.5 & 3.9 \\
\hline 35 & $\mathbf{5 . 0}$ & 4.5 \\
\hline $\begin{array}{c}40 \text { and } \\
\text { more }\end{array}$ & $\mathbf{5 . 0}$ & $\mathbf{5 . 0}$ \\
\hline
\end{tabular}

Bold numbers in Tab.1 show the optimal parameters of selected equipment (Liebherr and Volvo), specified for the projects of coal seams extracted on open pits of Kuzbass. So the height of layer set in projects of $5 \mathrm{~m}$, does not match conditions of extracting bedded coal seams with dip angle up to 30 degrees (in average $3.5 \mathrm{~m}$ ). Nevertheless, the share of bedded coal seams in Kuzbass coal deposits is estimated as $20-25 \%$ [12-16].

So we proposed the following decision. Based on the assumption of slope height similarity for coal barren and coal rich zones of open pit [17, 18], and considering the typical slope height in coal barren zone of $10 \mathrm{~m}$, we supposed to decrease the height of processing coal layer to $2.5 \mathrm{~m}$. It means extracting coal by hydraulic backhoes from "coaland-rock" panel with four layers of equal height [19, 20]. Note that the typical slope height in coal barren zone of 10 $\mathrm{m}$ is the average digging height for different kinds of excavating equipment: shovels, backhoes etc. 
Fig. 5 shows technological scheme of cutting trenches with simultaneous extracting coal seam with layers of 2.5 meters high.

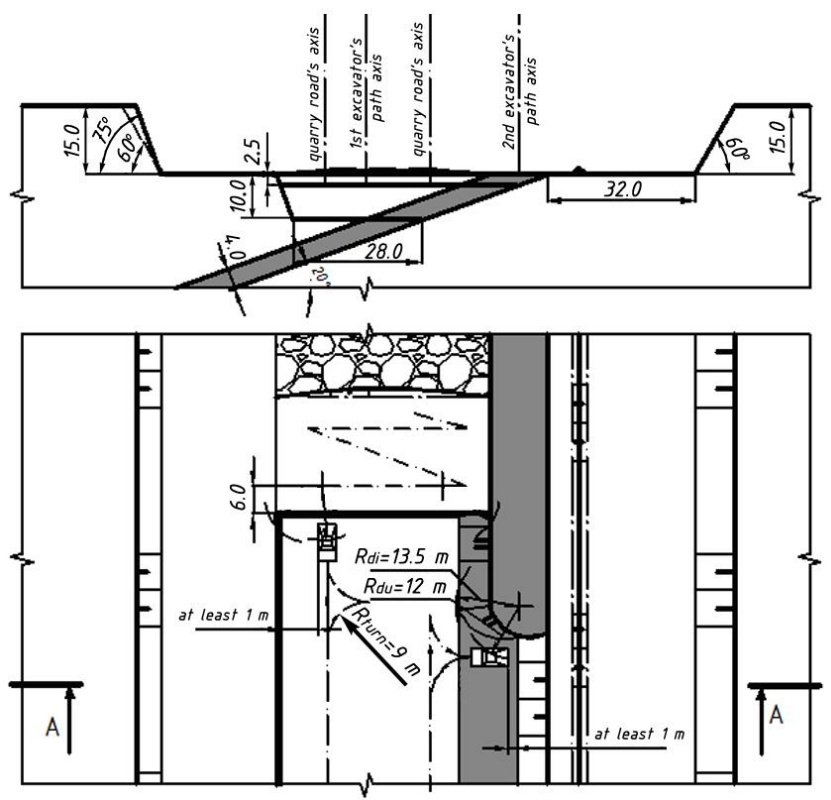

Fig. 5. The technological scheme of cutting trenches and excavation of inclined coal seam by hydraulic backhoes (excavation of the top layer is shown)

Fig. 5 shows the upper coal layer recovery. All the lower layers can be recovered in the same way [21]. The excavator (in our case - backhoe) moves zigzagged and loads exploded rock into trucks. After that it extracts the coal layer also with loading it into trucks. Under this scheme of open mining the maximum productivity of the excavator can be reached owing to its turning angle for downloading which does not exceed 30 degrees. Consequently the coal losses do not exceed reasonable limits. This scheme allows simultaneous use of two backhoes, every of which works in its own isolated sector - one for rock and another for coal [22]. We conclude that the implementation on this scheme will eliminate coal losses caused by un-excavation of coal seam.

\section{CONCLUSIONS}

Using hydraulic backhoes for coal recovery requires maximum engaging of their favorable parameters (in particular - full excavation without under-excavated prisms). It means adaptation of hydraulic backhoe for conditions of a certain open pit mine [23, 24]. In addition it should be noted that for excavation of exploded rock pile it is necessary to check the layer's height because of the lower stability angle for exploded rock. So it requires wider safety berm (the distance from the excavator's caterpillar to the upper edge of a slope) - up to $3 \mathrm{~m}$, whereas the safety berm for coal usually equals $1 \mathrm{~m}$, as it shown on Fig. 1 and 2 .

On these bases we recommend carefully using the parameters of hydraulic backhoes cinematic scheme, developed by their producers. In particular the maximum digging depth ( $8 \mathrm{~m}$ on Fig. 1 and 2, and $8.3 \mathrm{~m}$ on Fig 3 and 4) can be reached only with using the backhoe in perfect conditions, because they do not observe face parameters and rock stability.

\section{ACKNOWLEDGEMENTS}

The authors express their gratitude to the staff of Open Pit Mining Department of the T.F. Gorbachev Kuzbass State Technical University, the staff of Economy Department of National Research Tomsk Polytechnical University. The authors also express their sincere appreciation and gratitude to O.I. Litvin for his significant personal involvement and support.

\section{REFERENCES}

[1] Khoreshok A.. On side cutting bit when operating at sheerer drums. Ugol', 2002, vol. 7, pp. 10-11.

[2] Karpuz C., Hindistan M.A., and Bozdag T.A. New Method for Determining the Depth of Cut Using Power Shovel Monitoring. Journal of Mining Science, 2001, vol. 37(1), pp. 85-94.

[3] Zhironkin S.A.. Factoring and leasing development at coal mining industry of Kuzbass as an important element of its financial part. Ugol', 2001, vol. 4, pp. 29-30.

[4] Matushenko V.M . A method of comparing excavation equipment. Soviet Mining, 1975, vol. 11(5), pp. 576-578.

[5] Lesin Y.V., Lukyanova S.Y., and Tyulenev M.A. Mass transfer of dispersed particles in water filtration in macro-grained media. Journal of Mining Science, 2010, vol. 46(1), pp. 78-81.

[6] Kovalev V., Gerike B., Khoreshok A., and Gerike P. Preventive Maintenance of Mining Equipment Based on Identification of Its Actual Technical State. Taishan Academic Forum - Project on Mine Disaster Prevention and Control, 2014, pp. 184-189.

[7] Tyulenev M., Lesin Y., Zhironkin S., and Garina E. Coal producers waste water purification. Metallurgical and Mining Industry, 2016, vol. 2, pp. 52-56.

[8] Bereznyak M.M., and Kalinin A.V. Open mining in Kuzbass. FTPRPI, 1990, vol. 5, pp. 97-103.

[9] Zhironkin S.A., Tyulenev M.A., Zhironkina O.V., and Hellmer M.C. The global determinants of mining higher education development. Metallurgical and Mining Industry, 2016, vol. 2, pp. 62-67.

[10] Lekontsev Yu.M., Sazhin P.V., Temiryaeva O.A., and Khoreshok A.A. Two-Side Sealer Operation. Journal of Mining Science, 2013, 49(5), pp. 757-762.

[11] Lesin Y.V., Luk'yanova S.Y., and Tyulenev M.A. Formation of the composition and properties of dumps on the open-pit mines of Kuzbass. IOP Conference Series: Materials Science and Engineering, 2015, vol. 91 (1), 012093.

[12] Lokhanov B.N., Zakharov Yu.A., Bereznyak M.M., and Kalinin A.V. Open-cut mines in the Kuzbass: Progress and prospects. Soviet Mining, 1967, vol. 3 (5), pp. 523-527.

[13] Zhironkin S.A. Prospects and new possibilities investment attracting to Kuzbass coal mining industry. Ugol', 2002, vol. 6, pp. 3136.

[14] Aksenov V.V., Khoreshok A.A., and Beglyakov V.Yu. Justification of creation of an external propulsor for multipurpose shieldtype heading machine - GEO-WALKER. Applied Mechanics and Materials, 2013, vol. 379, pp. 20-23.

[15] Tyulenev M.A., and Lesin Y.V. Justification complex purification technology open-pit mines wastewater. Taishan: Academic Forum - Project on Mine Disaster Prevention and Control, 2014, pp. 441444.

[16] Selukov A.V. Advanced technology based on new technological and organizational principles of spatial development of front of mining operations at open pits. Taishan Academic Forum - Project on Mine Disaster Prevention and Control, 2014, pp. 156-160.

[17]Zhaoxue Che, and Hong Yang. Application of open-pit and underground mining technology for residual coal of end slopes. Mining Science and Technology (China), 2010, vol. 20 (2), pp. 266-270 
[18] Tyulenev M, Zhironkin S., and Litvin O. The low-cost technology of quarry water purifying using the artificial filters of overburden rock. Pollution Research, 2015, vol. 34 (4), pp. 825-830.

[19] Mattis A.R., Cheskidov V.I., and Labutin V.N . Choice of the hard rock surface mining machinery in Russia. Journal of Mining Science, 2012, vol. 48(2), pp. 329-338.

[20] Amar Prakash, Vemavarapu Mallika, Sita Ramachandra Murthy, and Kalendra Bahadur Singh. Rock excavation using surface miners: An overview of some design and operational aspects. International Journal of Mining Science and Technology, 2013, vol. 23(1), pp. 33-40.

[21] Vukotic I., Kecojevic V., Weishi Zhang, Qingxiang Cai, and Shuzhao Chen. Optimization of transport passage with dragline system in thick overburden open pit mine. International Journal of Mining Science and Technology, 2013, vol. 23(6), pp. 901-906.

[22] Khoreshok A.A., Mametyev L.E., Borisov A.Yu., and Vorobyev A.V. The distribution of stresses and strains in the mating elements disk tools working bodies of roadheaders. IOP Conference Series: Materials Science and Engineering, 2015, 91(1), 012084.

[23]Zhironkin S.A. Governmental factoring development of TEK Kuzbass. 2001, Ugol',vol. 6, pp. 62.

[24] Melchers, K., Kretschmann Yu., Goerke-Mallet P., Kleineberg K., Tyulenev M. Elementy i aspekty post-ekspluatatsionnogo perioda gornykh predpriyatij [Elements and aspects of post-operational period of mining enterprizes]. Vestnik Kuzbasskogo gosudarstvennogo tehnicheskogo universiteta, 2015, vol. 6, pp. 313. 